OPEN ACCESS

Edited by:

William Peter Cawthorn, University of Edinburgh, UK

Reviewed by:

Jan Tuckermann,

University of UIm, Germany

Luca Vanella,

University of Catania, Italy

*Correspondence: Michaela Tencerova mtencerova@health.sdu.dk

Specialty section:

This article was submitted to Bone Research,

a section of the journal

Frontiers in Endocrinology

Received: 04 May 2016 Accepted: 05 September 2016 Published: 21 September 2016

Citation:

Tencerova M and Kassem M (2016) The Bone Marrow-Derived Stromal Cells: Commitment and Regulation

of Adipogenesis.

Front. Endocrinol. 7:127. doi: 10.3389/fendo.2016.00127

\section{The Bone Marrow-Derived Stromal Cells: Commitment and Regulation of Adipogenesis}

\author{
Michaela Tencerova ${ }^{1,2 *}$ and Moustapha Kassem ${ }^{1,2,3}$ \\ ${ }^{1}$ Department of Molecular Endocrinology, Odense University Hospital, University of Southern Denmark, Odense, Denmark, \\ ${ }^{2}$ Danish Diabetes Academy, Novo Nordisk Foundation, Odense, Denmark, ${ }^{3}$ Stem Cell Unit, Department of Anatomy, Faculty \\ of Medicine, King Saud University, Riyadh, Saudi Arabia
}

Bone marrow (BM) microenvironment represents an important compartment of bone that regulates bone homeostasis and the balance between bone formation and bone resorption depending on the physiological needs of the organism. Abnormalities of BM microenvironmental dynamics can lead to metabolic bone diseases. BM stromal cells (also known as skeletal or mesenchymal stem cells) [bone marrow stromal stem cell (BMSC)] are multipotent stem cells located within BM stroma and give rise to osteoblasts and adipocytes. However, cellular and molecular mechanisms of BMSC lineage commitment to adipocytic lineage and regulation of BM adipocyte formation are not fully understood. In this review, we will discuss recent findings pertaining to identification and characterization of adipocyte progenitor cells in BM and the regulation of differentiation into mature adipocytes. We have also emphasized the clinical relevance of these findings.

Keywords: bone marrow stem cells, adipogenesis, secreted factors, bone marrow microenvironment, bone marrow stem cell subpopulations

\section{INTRODUCTION}

Bone marrow (BM) is an important compartment of bone, which regulates bone homeostasis. BM can also be perceived as an immune organ as it contains many different cell types secreting a large number of cytokines and immune modulatory factors. Finally, BM is a metabolic organ and has recently been demonstrated to regulate a whole body energy metabolism $(1,2)$.

The cellular composition of BM is complex as it contains hematopoietic stem cells giving rise to myeloid lineage including osteoclasts and lymphoid lineage giving rise to immune cells. It also contains a stroma compartment containing bone marrow stromal stem cells (BMSC) (also known as skeletal or mesenchymal stem cells) and their differentiated progeny of adipocytes and osteoblasts as well as endothelial cells, pericytes and neuronal cells. The cellular composition of BM changes with age, gender, and metabolic status $(3,4)$.

Bone turnover/remodeling is very dynamic and energetically demanding process that consists of two main phases: bone formation mediated by osteoblasts recruited from BMSC and bone resorption mediated by osteoclasts recruited from hematopoietic progenitors. Bone resorption and bone formation are coupled in time and space and there is a balance between the amount of bone resorbed by osteoclasts and the amount of bone formed by osteoblasts. These processes of coupling and balance are tightly regulated via several factors present in $\mathrm{BM}$ microenvironment and also via sympathetic central nervous system (2) (Figure 1). Imbalance between bone resorption and bone formation leads to metabolic bone diseases, including age-related bone loss and osteoporosis. 


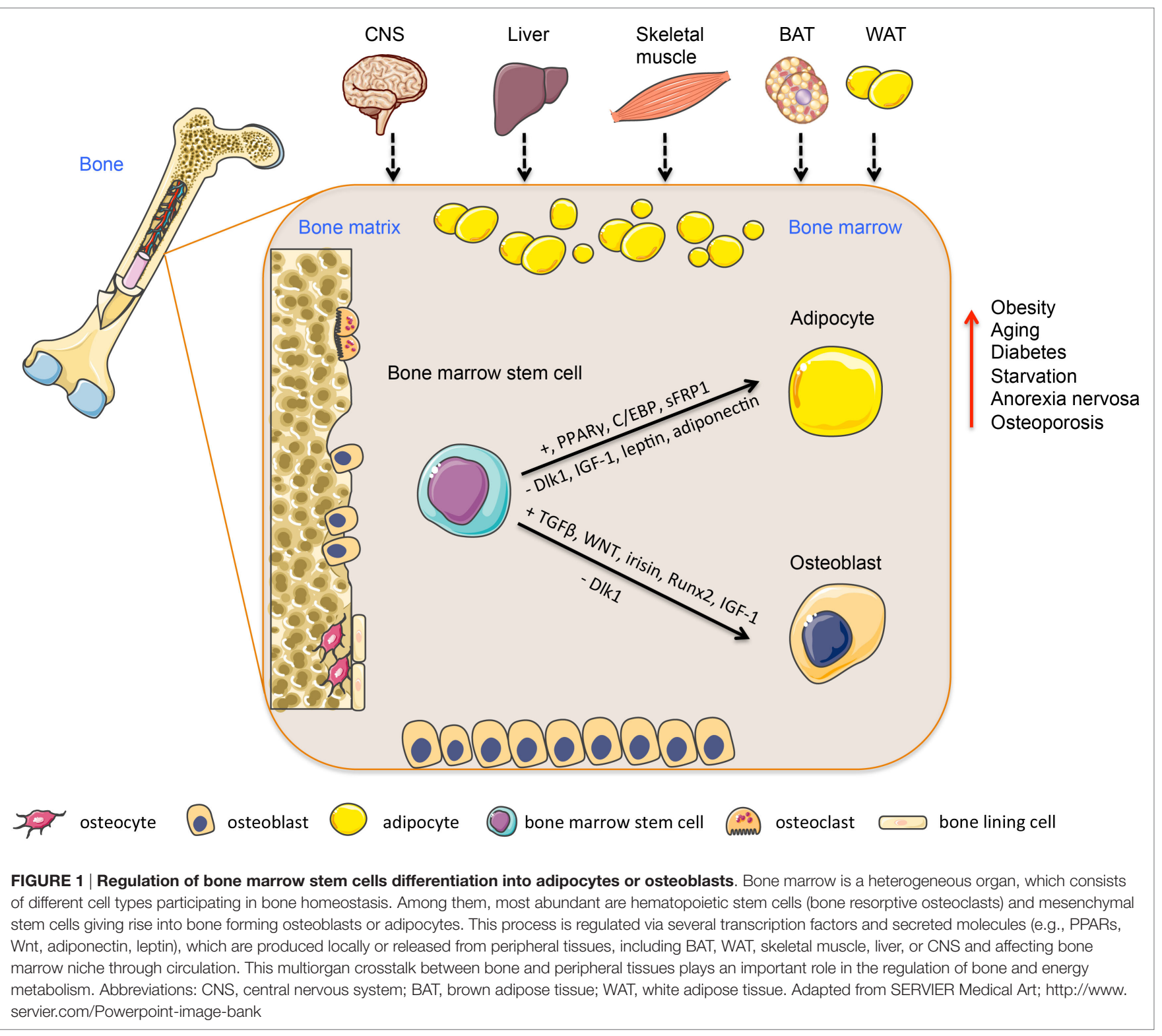

During the recent years, there has been an increasing interest in understanding the biology of BM adipocyte for a number of reasons. First, it is an abundant cell type in adult BM (5). Second, an increased BM adipose tissue mass has been reported in the conditions of low bone mass, suggesting an abnormal differentiation of BMSC as a possible pathogenetic mechanism to be investigated. Finally, the biological role of BM adipocytes and their differences and similarities with extramedullary adipocytes are not known and may be relevant to bone tissue homeostasis.

In this review, we will present an overview of the BM adipocyte differentiation and its regulation by a number of factors. We will also outline a number of specific signaling pathways that regulate BMSC lineage commitment to adipocytes versus osteoblasts and that can be targeted to enhance bone formation and increase bone mass.

\section{FROM BONE MARROW STEM CELLS TO COMMITTED ADIPOCYTIC CELLS IN THE BONE MARROW}

In vitro, BMSC are plastic-adherent cells, present within BM stroma and capable of clonal expansion and differentiation to osteoblasts and adipocytes. Currently, human BM adipocytes are thought to differentiate from BMSC as evidenced by a large body of both in vitro and in vivo studies (5). In mice, recent lineage tracing studies employing genetically modified mice, provided evidence for the common stem cell hypothesis for the presence of a common stem cells for osteoblastic and adipocytic cells $(6,7)$. Table 1 summaries the main characteristics of recently reported BMSC and progenitor cells identified and characterized based on lineage tracing studies employing expression of a number of markers. 
TABLE 1 | List of different skeletal progenitor cells in the bone marrow identified by specific cell surface markers and mediators.

\begin{tabular}{llll}
\hline Marker & Function & $\begin{array}{l}\text { Differentiation } \\
\text { potential }\end{array}$ & Reference \\
\hline Nestin & $\begin{array}{l}\text { A type VI intermediate } \\
\text { filament protein }\end{array}$ & HSC maintenance & (8) \\
Gremlin & $\begin{array}{l}\text { Inhibitor of BMP in TGF } \\
\text { beta signaling pathway }\end{array}$ & $\begin{array}{l}\text { Osteoblast, chondrocyte, } \\
\text { reticular cell }\end{array}$ \\
RANKL & $\begin{array}{l}\text { Receptor activator of } \\
\text { NFkB ligand }\end{array}$ & Adipocyte \\
LepR & Leptin receptor & Adipocyte \\
Sox9 & Transcription factor & Chondrocyte \\
Col2 & Type Il collagen & Chondrocyte \\
CD146 & Cell adhesion molecule & Osteoblast & (10) \\
CD34 & Cell adhesion molecule & Osteoblast & (12) \\
\hline
\end{tabular}

Single cell clonal analysis of cultured BM stromal cells revealed, in addition to BMSC, the presence of independent committed precursors for osteoblasts and adipocytes. Our study of Post et al. demonstrated the existence of these precursors within the murine BM stroma (16). Based on clonal selection, we were able to isolate and characterize the phenotype of two different precursor cell lines isolated from BM of 2- to 3-monthold mice: one cell line is committed to adipocyte differentiation and termed ${ }^{\text {adipo }} \mathrm{MSC}$ and another one committed to osteoblast and chondrocyte differentiation and termed boneMSC. The two cell lines exhibit distinct morphology and molecular signature. Based on the differentiation marker expression between these two cell lines, we have recently reported that CD34 is differentially expressed in ${ }^{\text {bone }} \mathrm{MSC}$ and not in ${ }^{\text {adipo }}$ MSC and that it can be used to prospective isolation of osteoblastic committed BMSC (15). Examples of studies using lineage tracing to identify committed precursor cells include the study of Yue et al. (11) that employed leptin receptor (LepR) to identify precursor cells with adipocyte differentiation potential. Mice with conditionally deleted LepR in limb bones enhanced osteogenesis and improved fracture healing (11). Another example is the study of Holt et al. (10) that demonstrated the presence of RANKL + preadipocytes in aged mice BM that support osteoclastogenesis. Similar findings have been confirmed in human $\mathrm{BM}(10,17)$. Interestingly, some lineage tracing studies show heterogeneity of BMSC populations with respect to their differentiation potential. Gremlin 1 (Grem1) is a secreted BMP inhibitor and involved in the regulation of adipogenesis in peripheral adipose acting via PPAR $\gamma$ (18). Recent study of Worthley et al. identified Gremlin 1 positive precursor cells that can differentiate into osteoblasts, chondrocytes, and reticular cells, but not to adipocytes (9). All these studies demonstrate the presence of complex cellular heterogeneity within the $\mathrm{BM}$ microenvironment and the presence of different committed BMSC subpopulations with a different differentiation potential, whose functions in the BM can be modulated independently during aging and metabolic diseases. It is also possible that these precursor cells number and functions are modulated by physiological conditions and energy demand. Since most of the above-mentioned studies were performed in
TABLE 2 | Cellular and molecular characteristics of bone marrow and extramedullary adipocytes.

\begin{tabular}{lccc}
\hline Parameters & $\begin{array}{c}\text { Bone marrow } \\
\text { adipocytes }\end{array}$ & $\begin{array}{l}\text { Extramedullary } \\
\text { adipocytes }\end{array}$ & Reference \\
\hline Adipocyte size & + & ++ & $(24)$ \\
Content of free fatty acids & + & ++ & $(28)$ \\
Cytokine expression & $\uparrow$ & $\downarrow$ & $(31)$ \\
Adipokine expression & $\downarrow$ & $\uparrow$ & $(27)$ \\
Stem cell markers & $\downarrow$ & $\uparrow$ & $(26)$ \\
expression & & & \\
Immunomodulatory & $\uparrow$ & & \\
properties & & &
\end{tabular}

mice, it is important to define the relevance of these findings to normal human physiology.

\section{BONE MARROW ADIPOCYTES VERSUS EXTRAMEDULLARY ADIPOCYTES}

Biological differences between BM medullary adipocytes and extramedullary adipocytes are not completely delineated. Several investigators have reported similarities between stromal cells isolated from the BM and subcutaneous stromal cells with respect to molecular phenotype and adipocyte differentiation capacity (19-22). However, significant differences have been observed in their responsiveness to adipocyte differentiation signals, as subcutaneous adipose tissue-derived stem cells (ASC) are better to differentiate to adipocytes compared to BMSC. BM and extramedullary adipocytes are different in cell size, expression of stem cell markers (e.g., Sox2, Nanog, Klf4), presence of extracellular matrix, free fatty acid content, proportion of immune cells in contact with adipocytes, levels of cytokine, and adipokine expression (23-28). Also BMSC have higher expression of inflammatory genes compared to ASC (29). Interestingly, the molecular signature analysis reveals that stromal cells from different tissue compartment are imprinted by their tissue of origin and ASC are enriched in adipogenesis-associated genes compared to MSC from other tissue compartments $(19,30-35)$. Other differences on cellular and molecular level have been reported (see listed in Table 2).

A recent paper of Liaw et al. has reported significant differences in lipid composition among different adipocytic cell lines derived from a variety of sources, including white and brown adipose tissue in mice and in adipocytes differentiated from 3T3-L1 cell line and ear mesenchymal cells (36). Unfortunately, the authors did not include BM adipocytes in their studies. This data highlight the differences in lipid metabolism in different adipocyte compartments, which may be mediated by exposure to different bioactive molecules in their microenvironment.

\section{BONE MARROW STROMAL STEM CELL COMMITMENT TO ADIPOCYTIC LINEAGE AND REGULATORY FACTORS}

Bone marrow stromal stem cell commitment to adipocytic lineage is a complex process, which is tightly controlled via several positive and negative regulatory factors activated possibly in a 
TABLE 3 | List of selected regulatory factors for adipocyte differentiation in bone marrow and adipose-derived stem cells.

\begin{tabular}{|c|c|c|c|c|c|}
\hline Gene name & Gene symbol & Category & $\begin{array}{l}\text { Bone marrow-derived stem } \\
\text { cells (BMSC) }\end{array}$ & $\begin{array}{l}\text { Adipose-derived } \\
\text { stem cells (ASC) }\end{array}$ & Reference \\
\hline Peroxisome proliferated-activated receptor $\gamma$ & PPAR $\gamma$ & Transcription factor & $\uparrow$ & $\uparrow$ & $(37,38)$ \\
\hline CAAT enhancer binding protein & $\mathrm{C} / \mathrm{EBP} \alpha / \beta$ & Transcription factor & $\uparrow \downarrow$ & $\uparrow$ & $(37-39)$ \\
\hline Adiponectin & Adipoq & Soluble mediator & $\downarrow$ & $\downarrow$ & $(40-42)$ \\
\hline Leptin & Lep & Soluble mediator & $\downarrow$ & $\downarrow$ & $(43-45)$ \\
\hline Secreted frizzled-related protein 1 & sFRP1 & Soluble mediator & $\uparrow$ & $\uparrow$ & $(46,47)$ \\
\hline Delta like-1/preadipocyte factor 1 & Dlk1/Pref-1 & Soluble mediator & $\downarrow$ & $\downarrow$ & $(48)$ \\
\hline Low-density lipoprotein receptor-related protein 5 & LRP5 & Soluble mediator & $\downarrow$ & $\uparrow$ & $(49-51)$ \\
\hline Bone morphogenic proteins & BMPs $(2,4,7)$ & Soluble mediator & $\begin{array}{l}\downarrow \uparrow \text { (depends on concentration } \\
\text { and differentiation cocktail) }\end{array}$ & $\uparrow$ (white and beige) & $(52-54)$ \\
\hline Insulin growth-like factor 1 & IGF-1 & Soluble mediator & $\downarrow$ & $\uparrow$ & $(55,56)$ \\
\hline Irisin, fibronectin type III domain-containing 5 & Fndc5 & Soluble mediator & $\downarrow$ & $\uparrow($ beige) & $(57-59)$ \\
\hline Fibroblast growth factor 21 & FGF-21 & Soluble mediator & $\uparrow$ & $\uparrow$ & $(60,61)$ \\
\hline Transforming growth factor beta & TGF $\beta$ & Soluble mediator & $\downarrow$ & $\downarrow$ & $(62,63)$ \\
\hline Interleukin 1 & IL1 & Soluble mediator & $\downarrow$ & $\downarrow$ & $(62)$ \\
\hline Interleukin 6 & IL6 & Soluble mediator & $\downarrow$ & $\downarrow$ & $(62)$ \\
\hline Tumor necrosis factor $\alpha$ & $\mathrm{TNF} \alpha$ & Soluble mediator & $\downarrow$ & $\downarrow$ & (62) \\
\hline Heme-oxygenase 1 & $\mathrm{HO}-1$ & Soluble mediator & $\downarrow$ & $\downarrow$ & $(64,65)$ \\
\hline
\end{tabular}

sequential cascade. These factors include steroid hormones, secreted cytokines/adipokines, and transcription factors. Most of these signaling molecules are known for their regulation of adipogenesis in bona fide ASC. Table 3 summarizes the effects of selected regulatory factors on adipocyte differentiation in BMSC and ASC that are discussed in the following paragraphs.

The most characterized transcription factor and a key regulator of adipogenesis is peroxisome proliferated-activated receptor gamma (PPAR $\gamma)(37,66)$. PPAR $\gamma$ belongs to a nuclear receptor superfamily, which is activated by lipophilic ligands. The activation of PPAR $\gamma$ is necessary and sufficient for adipocyte differentiation and also required for maintenance of differentiated state in BMSC and ASC (67-69). Inhibition of PPAR $\gamma$ in vitro impairs adipogenesis, while enhancing osteoblast differentiation in BMSC (67). In mice PPAR $\gamma$ deficiency leads to impaired development of adipose tissue when fed a high-fat diet (HFD) (70). PPAR $\gamma$ is also a target for insulin sensitizing drugs, such as thiazolidinediones in diabetes. However, their use for diabetic patients is associated with a decreased bone mass and increases a risk for fracture. The role of PPAR $\gamma$ activation in age-related increase of $\mathrm{BM}$ adipogenesis and decreased osteoblastogenesis has been discussed previously [for more information, see the reviews: Ref. $(3,38,68,71)]$.

Additional transcription factors involved in the regulation of adipogenesis are members of CAAT enhancer binding proteins (C/EBP) family: $\mathrm{C} / \mathrm{EBP} \alpha, \mathrm{C} / \mathrm{EBP} \beta, \mathrm{C} / \mathrm{EBP} \gamma$ and $\mathrm{C} / \mathrm{EBP} \delta$. Based on the studies performed in $3 \mathrm{~T} 3$ cell line, $\mathrm{C} / \mathrm{EBP}$ activation during adipocyte differentiation is synchronized in a temporal manner where early activation of $\mathrm{C} / \mathrm{EBP} \beta$ and $\mathrm{C} / \mathrm{EBP} \delta$ leads to induction of $\mathrm{C} / \mathrm{EBP} \alpha$. In BMSC, the function and activation of individual transcription factors exhibited a different pattern (72). Moreover, it has been shown that an isoform of $\mathrm{C} / \mathrm{EBP} \beta$, liver-enriched inhibitory protein (LIP), which lacks transcriptional binding domain, induces activation of Runx 2 and promotes osteogenesis in BMSC (39). C/EBPs crosstalk with PPAR $\gamma$ and regulate each other via a feedback loop $(38,68)$. C/EBP deficient mice exhibited impaired adipogenesis and insulin sensitivity (73-75). Moreover,
$\mathrm{C} / \mathrm{EBP} \beta$-deficient mice displayed reduced bone mineral density with decreased trabecular number $(76,77)$. These findings confirm an important role of C/EBPs in the early stage of MSC differentiation and their commitment (78).

The PPAR $\gamma$-regulated adipokines: leptin and adiponectin are primarily secreted by adipocytes and can regulate adipogenesis $(79,80)$. In vitro leptin inhibits adipogenesis and enhances osteoblastogenesis in human stromal marrow cells (43). On the other hand, leptin-deficient mice $o b / o b$ and LepR-deficient $d b /$ $d b$ mice exhibit an increased BM adiposity and low bone mass (79). Leptin regulates bone mass negatively indirectly via sympathetic nervous system (44). Interestingly, selective inhibition of LepR in osteoblastic cells has no effects on bone mass, whereas hypothalamic deletion of LepR leads to a phenotype similar to that of $o b / o b$ mice (81), suggesting that the main effects of leptin on bone are centrally mediated. In extramedullary adipocytes leptin impairs adipocyte function (e.g., insulin responsiveness and lipid metabolism) and inhibits lipogenesis (45). In addition, Aprath-Husmann et al. reported no effect of leptin on adipocyte differentiation in ASC of lean and obese subjects (82). Also, leptin levels increase with obesity and diabetes, diseases associated with bone fragility. Thus, leptin seems to exert multiple functions with direct and indirect effects on BM adipocytes and extramedullary adipocytes.

Adiponectin is an adipocyte-secreted factor with insulin sensitizing and anti-inflammatory effects. Adiponectin blocks adipocyte differentiation of BMSC and ASC suggesting an autocrine or paracrine negative feedback loop (40). In vitro adiponectin enhances osteoblast differentiation, increases osteoblast proliferation and maturation via cyclooxygenase 2 (Cox2)-dependent mechanism, and inhibits osteoclastogenesis $(41,83)$. However, in vivo effects on bone mass are more complex. Adiponectin regulates bone formation via opposite central and peripheral mechanisms through FoxO1 transcriptional factor. Adiponectin-deficient mice exhibit increased bone mass in young age but low bone mass during aging. This effect is explained by local inhibition of osteoblast proliferation and enhanced 
osteoblast apoptosis. During aging, this effect is antagonized by adiponectin-mediated effects on hypothalamic neurons that lead to decreased sympathetic tone and, consequently, increased bone mass and decreased energy expenditure (80). Overexpression of adiponectin in adipose tissue causes impairment of adipogenesis and increased preadipocyte factor 1 (Pref-1) expression, which inhibits adipogenesis in mice (42).

In obesity and type 2 diabetes, circulating levels of leptin and adiponectin are differentially regulated (up- and downregulated, respectively). However, their role in the regulation of $\mathrm{BM}$ adipogenesis has not been determined. Recently, Yue et al. demonstrated LepR signaling in BMSC promotes adipogenesis and inhibits osteoblastogenesis in response to diet (11). By contrast, activation of adiponectin receptor $\mathrm{R} 1$ (AdipR1) in osteoblasts results in enhanced bone formation via GSK-3 $\beta / \beta$ Catenin signaling (84). AdipoR1 deficient mice exhibit impaired osteoblast differentiation. The study of Yu et al. highlighted the importance of adiponectin signaling in BMSC mobilization and recruitment during bone fracture repair via increased secretion of stromal cell-derived factor 1 (SDF-1) in mice (85). Cawthorn et al. recently reported increased secretion of adiponectin from $\mathrm{BM}$ adipocytes in caloric restriction state that can contribute to its circulating levels (86), suggesting an important endocrine role of BM adipocytes in the regulation of whole body energy metabolism. However, this observation needs further investigation.

Novel factors, which have been identified in our laboratory based on proteomic analysis of secreted factors by committed BM adipocytic cells ( ${ }^{\text {adipo }} \mathrm{MSC}$ ) and committed BM osteoblastic cells ( ${ }^{\text {bone }} \mathrm{MSC}$ ), are secreted frizzled-related protein 1 (sFRP1) and Delta-like 1, also known as preadipocyte factor 1 (Dlk1/Pref-1) (16).

Secreted frizzled-related protein 1 is an inhibitor of Wnt signaling that sequester Wnts from their receptors. In vitro it inhibits osteoblastogenesis and promotes adipogensis of BMSC by blocking the Wnt signaling (46) In vivo sFRP1 inhibited bone formation. Similar effects of sFRP1 have been reported in preadipocytes and primary adipose tissue-derived cells $(87,88)$.

Delta-like 1 /preadipocyte factor 1 is a transmembrane protein, which belongs to a family of epidermal-growth-factor-like repeats containing proteins. Its extracellular domain is proteolytically cleaved by ADAM17/TACE and released as soluble factor circulating in body fluids include amniotic fluid and, hence, its name fetal antigen A (FA1) (89-91). Pref-1 is highly expressed in preadipocytes and its expression decreases during differentiation. Pref-1 overexpression in 3T3-L1 cells blocks adipogenesis (92). Pref-1 regulates adipocyte differentiation via FOXA2 (93), KLF6 (94), and KLF2 (95). Our group has reported that overexpression of Dlk1 in human BMSC inhibits adipocyte and osteoblastic differentiation (48). Interestingly, Dlk1/Pref-1 inhibited differentiation of MSC downstream of $\mathrm{C} / \mathrm{EBP} \beta$ during adipocytic differentiation and Cbfa1/Runx2 during osteoblastic differentiation, suggesting that Dlk1/Pref-1 maintains MSC in a progenitor state. Importantly, we showed a negative effect of soluble FA1 on bone formation in ex vivo neonatal calvaria organ cultures. Also transgenic mice with Dlk1 overexpression had reduced fat and bone mass (96). We have also recently reported that FA1 acts as a link between bone and whole body energy metabolism and it interacts with osteocalcin (97).

Additional negative regulators of adipocyte differentiation of BMSC include molecules in Wnt signaling pathway that consists of several ligands, receptors, co-receptors and transcriptional mediators, e.g., $\beta$-catenin, which blocks PPAR $\gamma$ and its downstream-regulated genes $(98,99)$.

Low-density lipoprotein receptor-related protein 5 (LRP5) is a Wnt co-receptor and is involved in activation of canonical Wnt signaling $(49,50,100)$. It has been shown to inhibit adipogenesis and promote osteoblastogenesis in BMSC. A gain of function mutation in Lrp5, a clinical condition known as a high-bone-mass phenotype, leads to inhibition of adipogenesis and enhances osteoblastogenesis, which is associated with increased bone mass. On the other hand, Lrp5 loss of function mutation causes severe osteoporosis in mice and humans $(49,50,100,101)$. Recent paper of Loh et al. (49) demonstrated enhanced adipogenesis in lower body fat, e.g., gluteal adipose tissue in high-bone-mass phenotype patients. This finding confirms the results of Palsgaard et al., who reported impaired adipogenesis in LRP5-deficient preadipocytes due to an interaction between LRP5 and insulin receptor (51).

Bone morphogenetic proteins (BMPs) are members of the transforming growth factor $\beta$ (TGF $\beta$ ) superfamily that were originally identified based on their ability to induce ectopic bone formation. BMPs have pleiotropic developmental actions, important for stem cell self-renewal and lineage commitment and differentiation (102). BMP4 promotes adipogenesis in peripheral adipose tissue progenitors by increasing transcription activity of PPAR $\gamma(18,103)$. However, dependent on BMP concentration and receptor activation, they exert different lineage differentiation effects (104). Low concentrations of BMP-2 and BMP-7 induce adipocytic differentiation, whereas high concentrations promote differentiation toward chondrocytes and osteoblasts $(105,106)$. BMP signaling through type IB BMP receptor (BMPR-IB) plays a crucial role in mediating osteoblast differentiation of BMSC by a Dlx5/Runx2-mediated pathway, while activation of the type IA BMP receptor (BMPR-IA) in BMSC induces PPARs expression and promotes adipocyte differentiation $(107,108)$.

Another signaling pathway involved in the regulation of adipogenesis is insulin/insulin-like growth factor (IGF-1) pathway $(55,56,109)$. IGF-1 has pleiotropic functions in several tissues with regulatory effects on cell proliferation and cell differentiation. It is the most abundant growth factor in the bone matrix. Deletion of IGF-1 in osteocytes caused impaired developmental bone growth in mice (110). IGF-1-osteoblast deficient animals exhibit impaired bone formation and reduction in bone mass (111). Mice treated with recombinant IGF-1 exhibited enhanced bone formation and osteogenesis via activation of mTOR signaling (112). In adipose tissue, IGF-1 plays an important role in adipocyte differentiation, especially in lineage commitment stage where insulin acts predominantly through IGF-1 receptors, which are highly expressed in preadipocytes compared to insulin receptors (113). Blocking downstream molecules in insulin signaling pathway inhibits adipogenesis in preadipocytes (56). Importantly, IGF-1 is also involved in the regulation of energy metabolism and glucose uptake in insulin responsive cells. Therefore, IGF-1 exerts multiple functions dependent on cellular energy needs. However, 
its role in the regulation of energy metabolism in BMSC and BM adipocytes is not known.

Muscle-secreted proteins, known as myokines, represent a group of regulatory molecules with expanding role in crosstalk between muscle and different organs in the body and with regulatory functions on bone and energy metabolism.

Irisin is a newly identified myokine released from skeletal muscle during exercise through peroxisome proliferator-activated receptor gamma coactivator 1 (PGC1) activation that mediates expression of membrane protein Fibronectin type III domaincontaining protein 5 (FNDC5). This is a precursor molecule for irisin, which is subsequently cleaved as the myokine (114). Irisin has a browning effect on white adipose tissue via upregulating uncoupling protein 1 (UCP1) through p38 MAPK and ERK (57, 114). Moreover, recent studies demonstrated that irisin positively affects skeletal system, i.e., it enhances osteoblastogenesis in vitro and in vivo $(58,59)$.

Fibroblast growth factor 21 (FGF21) has been identified as a circulating hepatokine with effects on glucose and lipid metabolism. FGF21 is also secreted from adipose tissue and skeletal muscle (115). It exerts a positive effect on adipogenesis via activation of PPAR $\gamma$ in BMSC and adipose tissue progenitors. FGF21-deficient mice exhibit high bone mass and decreased fat formation. Reciprocally, mice overexpressing FGF21 exhibit reduced bone mass $(60,61)$. In older men, high serum levels of FGF21 are associated with low bone mass (116).

Inflammatory cytokines are mostly produced by immune cells and play an important role in the regulation of bone remodeling and adipocyte formation.

Transforming growth factor beta is a cytokine of the TGF superfamily that promotes preadipocyte proliferation and inhibits adipocyte differentiation. Overexpression of TGF $\beta$ in mice leads to impaired adipose tissue development. On the other hand, TGF $\beta$-deficient mice display impaired bone growth and mineralization (117). TGF $\beta$ mediates its inhibitory function on adipogenesis via $\mathrm{SMAD} 3$, which acts on $\mathrm{C} / \mathrm{EBP} \alpha(56,118)$.

The effects of the pro-inflammatory cytokines: interleukin 1 (IL1), interleukin 6 (IL6), and tumor necrosis factor alpha (TNF $\alpha$ ) on preadipocytes and BMSC are similar (62). They inhibit adipogenesis by reducing PPAR $\gamma$ and $\mathrm{C} / \mathrm{EBP} \alpha$ expression and by blocking insulin action via decreasing Glut4 expression in preadipocytes (119). TNF $\alpha$ and IL1 suppress adipocyte differentiation by activation of the TAK1/TAB1/NIK cascade, which in turn inhibits PPAR $\gamma$ activity (120). IL1 and TNF $\alpha$ inhibit adipocyte cell proliferation by activation of several distinct intracellular signaling pathways (e.g., JNK, p38 MAPK) (119, 121, 122). Moreover, IL6 maintains BMSC in undifferentiated state through ERK1/2-mediated mechanism during bone fracture healing (123). On the other hand IL6 enhances osteoblast differentiation of BMSC by decreasing Sox 2 expression (124). In estrogen-deficient mouse model, IL6-deficient mice are protected from ovariectomy-induced bone loss (125), suggesting a role in mediating estrogen-deficiency-related bone loss (125).

Heme-oxigenase $1(\mathrm{HO}-1)$ is a rate-limiting enzyme with antiinflammatory properties, activated by oxidative stress, which was reported to regulate commitment of human BMSC differentiation to osteoblastic cells. HO-1 acts as an inhibitor of adipogenesis by enhancing Wnt signaling (64). Similar effects were observed in ASC of obese mice, which were treated with $\mathrm{HO}-1$ inducer that led to decreased adiposity in peripheral adipose and BM along with a positive effect on insulin sensitivity (65).

Taken together, the above-mentioned regulatory factors share similar signaling pathways for the regulation of adipocyte differentiation in BMSC and ASC. However, some of these factors, e.g., BMP, IGF-1, and LRP5 display different effects depending on the origin of MSCs, suggesting an important role of local microenvironment. These findings are relevant to the design of potential drugs for targeting BMSC in the context of regulation of bone and energy metabolism. Figure 1 summarizes factors regulating BMSC differentiation and their associated signaling pathways.

\section{MICRO RNA AND REGULATING GENETIC NETWORKS IN ADIPOCYTIC DIFFERENTIATION}

Micro RNAs (miRNA) are evolutionary conserved short noncoding RNA molecules (containing about 22 nucleotides) that function in RNA silencing and post-transcriptional regulation of gene expression. Accumulating evidence suggests that miRNA regulate fate decisions of stem cells, including self-renewal and differentiation $(126,127)$.

Several groups have employed global miRNA gene expression profiling during differentiation of human BMSC to identify several miRNAs that regulate BMSC fate and that act as a molecular switch to control adipocyte and osteoblast differentiation fate. Most of miRNAs regulate gene expression of key molecules involved in BMSC differentiation, such as PPAR $\gamma, \mathrm{C} / \mathrm{EBP}$, Runx2, Wnt $/ \beta$-catenin, Lrp5/6, and so on. For example, recent study of Hamam et al. identified miR320 family, whose upregulation in human BMSC enhanced adipocyte differentiation. The biologically relevant gene targets for miR-320c are RUNX2, MIB1 (mindbomb E3 ubiquitin protein ligase 1), PAX6 (paired box 6), YWHAH, and ZWILCH (128). Other miRNAs that have been reported as regulators of adipogenesis include miR-143, -24, -31, $-30 c$, and $-642 a-3 p$. More detailed description of their function in the regulation of BMSC differentiation is summarized in these recently published reviews $(127,129,130)$. Thus, targeting different miRNAs represents a potential tool for a molecular therapy to regulate BMSC differentiation fate.

\section{BONE MARROW ADIPOGENESIS IN AGING, OSTEOPOROSIS, AND METABOLIC DISORDERS}

In vivo, it has been shown an inverse relationship between bone and fat formation in the BM cavity $(1,131,132)$. For examples, observed abnormalities of bone remodeling during aging, osteoporosis, estrogen deficiency, chronic glucocorticoid (GC) treatment, immobilization, anorexia nervosa, and Cushing disease are associated with increased adipose tissue accumulation in the BM and decreased bone mass $(3,133-135)$. One of the cellular explanations that has been put forward to explain this inverse relationship between bone and fat tissue mass in the BM is 
differentiation reprograming of BMSC toward adipocyte instead of osteoblastic fate (136-138). Moerman et al. reported that aging activates adipogenic and suppresses osteogenic differentiation programs in BMSC in mice (139). Molecular mechanism behind this reprograming machinery is not completely delineated. It has been shown that several extracellular signaling proteins have overlapping roles in BMSC adipogenesis and osteoblastogenesis by modulating the expression and/or activity of adipocyte-specific (e.g., PPARs) or osteoblast-specific (e.g., Runx2 and osterix) transcription factors. Some of these factors play opposing roles in lineage determination, while others function in complementary fashion. Schilling et al. using whole genome analyses identified several genes that could play a role in osteoblast versus adipocyte differentiation of BMSC (138).

Obesity and diabetes are highly prevalent diseases, in which bone mass is also affected (140). Several studies have demonstrated that metabolic complications of diabetes are associated with increased risk for bone fractures. However, it is not clear whether these effects are mediated by changes in BM adipose tissue. Bredella et al. found positive correlation between visceral adipose tissue and $\mathrm{BM}$ adiposity as measured in vertebrae of obese premenopausal women. Interestingly, this finding correlates with decreased BMD, even after correcting for the degree of obesity (141). An in vitro study reported that incubating BMSC with sera obtained from overweight persons promotes in vitro adipocyte differentiation and diminishes osteoblast differentiation (142), suggesting that secreted factors/nutrients present in circulation can affect the differentiation process of BMSC (142). In HFD-induced obesity in mice, an increased osteoclastic bone resorption associated with a lower trabecular bone mass is observed (143). Indeed, saturated fatty acids impair osteoblastogenesis, enhance adipogenesis, and affect cell survival and proliferation of human BMSC $(144,145)$. Other animal study reported impairment of mitochondrial function and apoptosis of BMSC in obese mice (146).

An increased BM adiposity has been reported in type 1 and type 2 diabetes (T1D and T2D). However, in T1D, there is a decrease in bone mass, whereas $\mathrm{T} 2 \mathrm{D}$ is characterized by no change or higher bone mass and paradoxically increased risk for osteoporotic fractures (147-150). Studies are underway to examine the role of impaired glucose metabolism and its associated hyperglycemia and hyperinsulinemia on the biological functions of BMSC. This area of research has also been strengthened by the discovery of osteocalcin as a bone secreted hormone that regulates insulin secretion, proliferation of $\beta$-cells, and overall energy metabolism in mice $(151,152)$ and FA1 as a negative regulator of osteocalcin-induced hypoglycemia (97).

\section{TARGETING BONE MARROW ADIPOCYTES TO INCREASE BONE MASS}

Several studies have examined the possibility of reverting the adipocyte differentiation fate of BMSC to bone forming osteoblasts as an approach to increased bone mass during aging and in osteoporosis. A number of molecular studies have investigated therapeutic potential of several factors as regulators of BMSC differentiation fate, which included hormone replacement therapy/ small molecules with antagonistic/agonistic effect or neutralizing antibodies.

An example is sclerostin (SOST), which is a glycoprotein produced by osteocytes and acts as an inhibitor of Wnt signaling. SOST inhibits bone formation and increases bone adiposity through possibly targeting differentiation of BMSC $(153,154)$. Treatment with humanized antibodies against SOST is currently in phase III trials for osteoporosis management (155). Another molecule with a similar function as SOST is Dickkopf-1 (DKK1), which negatively regulates Wnt signaling (156). Growth factors, such as BMPs or activin A, represent other anabolic agents for a potential treatment (157). Recent study of Florio et al. reported promising results on the use of bispecific antibody targeting SOST and DKK1 with an enhanced effect on bone formation in rodents and non-human primates (158). However, further clinical studies are needed to investigate the effectiveness of combined treatment, especially in patients with severe osteoporosis.

Some anti-diabetic drugs designed to improve insulin sensitivity and adipogenesis in the peripheral tissues have unfortunately the side effects on bone mass with increased fracture risk, e.g., thiazolidinediones due to partly enhanced BM adiposity $(71,159,160)$. Thus, one of the research goals is to design antidiabetic drugs with minimal negative effects on bone. Recently used anti-diabetic drugs in the clinic include the incretin-based therapies (GLP-1 receptor agonists, DPP-4 inhibitors) and drugs targeting sodium-glucose co-transporter 2 (SGLT2)-inhibitors. However, their effects on bone mass and fracture risk need to be determined (161).

\section{CONCLUSION/FUTURE PERSPECTIVES}

MSC commitment to differentiate into osteoblasts or adipocytes and, consequently, the balance between bone mass and BM adipose tissue mass is a complex and dynamic process, which is regulated and fine tuned by a large number of bioactive molecules. The sequential cascade of these processes and how they modulate BMSC differentiation is currently under intensive investigation. Future studies need to identify the biological functions of BM adipocytes not only in relation to bone remodeling but also as part of the overall regulation of energy metabolism. The findings of novel secreted molecules involved in the regulation of cellular fate of BMSC provide new possible anabolic therapies for treating clinical conditions of low bone mass and possibly disturbances in energy metabolism.

\section{AUTHOR CONTRIBUTIONS}

MT and MK researched data, wrote manuscript and reviewed the final manuscript.

\section{ACKNOWLEDGMENTS}

This work was supported by The Novo Nordisk Foundation NNF15OC0016284, Interregional EU grant Bonebank 16-1.0-15, Inovationsfonden, Denmark and OUH Research grant 15-A845. MT is supported by a Postdoctoral fellowship from the Novo Nordisk Foundation through the Danish Diabetes Academy. 


\section{REFERENCES}

1. Gimble JM, Zvonic S, Floyd ZE, Kassem M, Nuttall ME. Playing with bone and fat. J Cell Biochem (2006) 98:251-66. doi:10.1002/jcb.20777

2. Lecka-Czernik B, Rosen CJ. Energy excess, glucose utilization, and skeletal remodeling: new insights. J Bone Miner Res (2015) 30:1356-61. doi:10.1002/ jbmr.2574

3. Justesen J, Stenderup K, Ebbesen EN, Mosekilde L, Steiniche T, Kassem M. Adipocyte tissue volume in bone marrow is increased with aging and in patients with osteoporosis. Biogerontology (2001) 2:165-71. doi:10.102 3/A:1011513223894

4. Rosen CJ, Ackert-Bicknell C, Rodriguez JP, Pino AM. Marrow fat and the bone microenvironment: developmental, functional, and pathological implications. Crit Rev Eukaryot Gene Expr (2009) 19:109-24. doi:10.1615/ CritRevEukarGeneExpr.v19.i2.20

5. Gimble JM, Robinson CE, Wu X, Kelly KA. The function of adipocytes in the bone marrow stroma: an update. Bone (1996) 19:421-8. doi:10.1016/ S8756-3282(96)00258-X

6. Kassem M, Bianco P. Skeletal stem cells in space and time. Cell (2015) 160:17-9. doi:10.1016/j.cell.2014.12.034

7. Chan CK, Seo EY, Chen JY, Lo D, McArdle A, Sinha R, et al. Identification and specification of the mouse skeletal stem cell. Cell (2015) 160:285-98. doi:10.1016/j.cell.2014.12.002

8. Mendez-Ferrer S, Michurina TV, Ferraro F, Mazloom AR, Macarthur $\mathrm{BD}$, Lira SA, et al. Mesenchymal and haematopoietic stem cells form a unique bone marrow niche. Nature (2010) 466:829-34. doi:10.1038/ nature09262

9. Worthley DL, Churchill M, Compton JT, Tailor Y, Rao M, Si Y, et al. Gremlin 1 identifies a skeletal stem cell with bone, cartilage, and reticular stromal potential. Cell (2015) 160:269-84. doi:10.1016/j.cell.2014.11.042

10. Holt V, Caplan AI, Haynesworth SE. Identification of a subpopulation of marrow MSC-derived medullary adipocytes that express osteoclast-regulating molecules: marrow adipocytes express osteoclast mediators. PLoS One (2014) 9:e108920. doi:10.1371/journal.pone.0108920

11. Yue R, Zhou BO, Shimada IS, Zhao Z, Morrison SJ. Leptin receptor promotes adipogenesis and reduces osteogenesis by regulating mesenchymal stromal cells in adult bone marrow. Cell Stem Cell (2016). doi:10.1016/j. stem.2016.02.015

12. Akiyama H, Kim JE, Nakashima K, Balmes G, Iwai N, Deng JM, et al. Osteochondroprogenitor cells are derived from Sox9 expressing precursors. Proc Natl Acad Sci U S A (2005) 102:14665-70. doi:10.1073/pnas.0504750102

13. Grant TD, Cho J, Ariail KS, Weksler NB, Smith RW, Horton WA. Col2GFP reporter marks chondrocyte lineage and chondrogenesis during mouse skeletal development. Dev Dyn (2000) 218:394-400. doi:10.1002/ (SICI)1097-0177(200006)218:2<394::AID-DVDY12>3.0.CO;2-I

14. Harkness L, Zaher W, Ditzel N, Isa A, Kassem M. CD146/MCAM defines functionality of human bone marrow stromal stem cell populations. Stem Cell Res Ther (2016) 7:4. doi:10.1186/s13287-015-0266-Z

15. Abdallah BM, Al-Shammary A, Skagen P, Abu Dawud R, Adjaye J, Aldahmash A, et al. CD34 defines an osteoprogenitor cell population in mouse bone marrow stromal cells. Stem Cell Res (2015) 15:449-58. doi:10.1016/j. scr.2015.09.005

16. Post S, Abdallah BM, Bentzon JF, Kassem M. Demonstration of the presence of independent pre-osteoblastic and pre-adipocytic cell populations in bone marrow-derived mesenchymal stem cells. Bone (2008) 43:32-9. doi:10.1016/j. bone.2008.03.011

17. Takeshita S, Fumoto T, Naoe Y, Ikeda K. Age-related marrow adipogenesis is linked to increased expression of RANKL. J Biol Chem (2014) 289:16699-710. doi:10.1074/jbc.M114.547919

18. Gustafson B, Hammarstedt A, Hedjazifar S, Hoffmann JM, Svensson PA, Grimsby J, et al. BMP4 and BMP antagonists regulate human white and beige adipogenesis. Diabetes (2015) 64:1670-81. doi:10.2337/db14-1127

19. Liu TM, Martina M, Hutmacher DW, Hui JH, Lee EH, Lim B. Identification of common pathways mediating differentiation of bone marrow- and adipose tissue-derived human mesenchymal stem cells into three mesenchymal lineages. Stem Cells (2007) 25:750-60. doi:10.1634/stemcells.2006-0394

20. Winter A, Breit S, Parsch D, Benz K, Steck E, Hauner H, et al. Cartilage-like gene expression in differentiated human stem cell spheroids: a comparison of bone marrow-derived and adipose tissue-derived stromal cells. Arthritis Rheum (2003) 48:418-29. doi:10.1002/art.10767

21. Zuk PA, Zhu M, Ashjian P, De Ugarte DA, Huang JI, Mizuno H, et al. Human adipose tissue is a source of multipotent stem cells. Mol Biol Cell (2002) 13:4279-95. doi:10.1091/mbc.E02-02-0105

22. Vishnubalaji R, Al-Nbaheen M, Kadalmani B, Aldahmash A, Ramesh T. Comparative investigation of the differentiation capability of bone-marrowand adipose-derived mesenchymal stem cells by qualitative and quantitative analysis. Cell Tissue Res (2012) 347:419-27. doi:10.1007/s00441-011-1306-3

23. Griffith JF, Yeung DK, Ahuja AT, Choy CW, Mei WY, Lam SS, et al. A study of bone marrow and subcutaneous fatty acid composition in subjects of varying bone mineral density. Bone (2009) 44:1092-6. doi:10.1016/j.bone.2009.02.022

24. Trubowitz S, Bathija A. Cell size and plamitate-1-14c turnover of rabbit marrow fat. Blood (1977) 49:599-605.

25. Tavassoli M. Fatty Involution of Marrow and the Role of Adipose Tissue in Hemopoiesis. Clifton, NJ: Humana (1989).

26. Poloni A, Maurizi G, Serrani F, Mancini S, Zingaretti MC, Frontini A, et al. Molecular and functional characterization of human bone marrow adipocytes. Exp Hematol (2013) 41:558-566e2. doi:10.1016/j.exphem.2013. 02.005

27. Krings A, Rahman S, Huang S, Lu Y, Czernik PJ, Lecka-Czernik B. Bone marrow fat has brown adipose tissue characteristics, which are attenuated with aging and diabetes. Bone (2012) 50:546-52. doi:10.1016/j.bone.2011. 06.016

28. Bojin FM, Gruia AT, Cristea MI, Ordodi VL, Paunescu V, Mic FA. Adipocytes differentiated in vitro from rat mesenchymal stem cells lack essential free fatty acids compared to adult adipocytes. Stem Cells Dev (2012) 21:507-12. doi:10.1089/scd.2011.0491

29. Gimble JM, Katz AJ, Bunnell BA. Adipose-derived stem cells for regenerative medicine. Circ Res (2007) 100:1249-60. doi:10.1161/01. RES.0000265074.83288.09

30. Aldahmash A, Zaher W, Al-Nbaheen M, Kassem M. Human stromal (mesenchymal) stem cells: basic biology and current clinical use for tissue regeneration. Ann Saudi Med (2012) 32:68-77.

31. Elman JS, Li M, Wang F, Gimble JM, Parekkadan B. A comparison of adipose and bone marrow-derived mesenchymal stromal cell secreted factors in the treatment of systemic inflammation. J Inflamm (Lond) (2014) 11:1. doi:10.1186/1476-9255-11-1

32. Shafiee A, Seyedjafari E, Soleimani M, Ahmadbeigi N, Dinarvand P, Ghaemi $\mathrm{N}$. A comparison between osteogenic differentiation of human unrestricted somatic stem cells and mesenchymal stem cells from bone marrow and adipose tissue. Biotechnol Lett (2011) 33:1257-64. doi:10.1007/s10529-011-0541-8

33. Maumus M, Peyrafitte JA, D'Angelo R, Fournier-Wirth C, Bouloumie A, Casteilla L, et al. Native human adipose stromal cells: localization, morphology and phenotype. Int J Obes (Lond) (2011) 35:1141-53. doi:10.1038/ ijo.2010.269

34. De Ugarte DA, Morizono K, Elbarbary A, Alfonso Z, Zuk PA, Zhu M, et al. Comparison of multi-lineage cells from human adipose tissue and bone marrow. Cells Tissues Organs (2003) 174:101-9. doi:10.1159/000071150

35. Kim D, Monaco E, Maki A, de Lima AS, Kong HJ, Hurley WL, et al. Morphologic and transcriptomic comparison of adipose- and bone-marrow-derived porcine stem cells cultured in alginate hydrogels. Cell Tissue Res (2010) 341:359-70. doi:10.1007/s00441-010-1015-3

36. Liaw L, Prudovsky I, Koza RA, Anunciado-Koza RV, Siviski ME, Lindner V, et al. Lipid profiling of in vitro cell models of adipogenic differentiation: relationships with mouse adipose tissues. J Cell Biochem (2016) 117(9):2182-93. doi: $10.1002 /$ jcb. 25522

37. Smas CM, Sul HS. Control of adipocyte differentiation. Biochem J (1995) 309(Pt 3):697-710. doi:10.1042/bj3090697

38. Siersbaek R, Nielsen R, Mandrup S. Transcriptional networks and chromatin remodeling controlling adipogenesis. Trends Endocrinol Metab (2012) 23:56-64. doi:10.1016/j.tem.2011.10.001

39. Hata K, Nishimura R, Ueda M, Ikeda F, Matsubara T, Ichida F, et al. A CCAAT/enhancer binding protein beta isoform, liver-enriched inhibitory protein, regulates commitment of osteoblasts and adipocytes. $\mathrm{Mol}$ Cell Biol (2005) 25:1971-9. doi:10.1128/MCB.25.5.1971-1979.2005

40. Yokota T, Meka CS, Medina KL, Igarashi H, Comp PC, Takahashi M, et al. Paracrine regulation of fat cell formation in bone marrow cultures 
via adiponectin and prostaglandins. JClin Invest (2002) 109:1303-10. doi:10.1172/JCI0214506

41. Lee HW, Kim SY, Kim AY, Lee EJ, Choi JY, Kim JB. Adiponectin stimulates osteoblast differentiation through induction of COX2 in mesenchymal progenitor cells. Stem Cells (2009) 27:2254-62. doi:10.1002/stem.144

42. Bauche IB, El Mkadem SA, Pottier AM, Senou M, Many MC, Rezsohazy R, et al. Overexpression of adiponectin targeted to adipose tissue in transgenic mice: impaired adipocyte differentiation. Endocrinology (2007) 148:1539-49. doi:10.1210/en.2006-0838

43. Thomas T, Gori F, Khosla S, Jensen MD, Burguera B, Riggs BL. Leptin acts on human marrow stromal cells to enhance differentiation to osteoblasts and to inhibit differentiation to adipocytes. Endocrinology (1999) 140:1630-8. doi:10.1210/en.140.4.1630

44. Ducy P, Amling M, Takeda S, Priemel M, Schilling AF, Beil FT, et al. Leptin inhibits bone formation through a hypothalamic relay: a central control of bone mass. Cell (2000) 100:197-207. doi:10.1016/ S0092-8674(00)81558-5

45. Harris RB. Direct and indirect effects of leptin on adipocyte metabolism. Biochim Biophys Acta (2014) 1842:414-23. doi:10.1016/j.bbadis.2013.05.009

46. Taipaleenmaki H, Abdallah BM, AlDahmash A, Saamanen AM, Kassem $\mathrm{M}$. Wnt signalling mediates the cross-talk between bone marrow derived pre-adipocytic and pre-osteoblastic cell populations. Exp Cell Res (2011) 317:745-56. doi:10.1016/j.yexcr.2010.12.015

47. Abdallah BM, Kassem M. New factors controlling the balance between osteoblastogenesis and adipogenesis. Bone (2012) 50:540-5. doi:10.1016/j. bone.2011.06.030

48. Abdallah BM, Jensen CH, Gutierrez G, Leslie RG, Jensen TG, Kassem M. Regulation of human skeletal stem cells differentiation by Dlk1/Pref-1.J Bone Miner Res (2004) 19:841-52. doi:10.1359/jbmr.040118

49. Loh NY, Neville MJ, Marinou K, Hardcastle SA, Fielding BA, Duncan EL, et al. LRP5 regulates human body fat distribution by modulating adipose progenitor biology in a dose- and depot-specific fashion. Cell Metab (2015) 21:262-72. doi:10.1016/j.cmet.2015.01.009

50. Qiu W, Andersen TE, Bollerslev J, Mandrup S, Abdallah BM, Kassem M. Patients with high bone mass phenotype exhibit enhanced osteoblast differentiation and inhibition of adipogenesis of human mesenchymal stem cells. J Bone Miner Res (2007) 22:1720-31. doi:10.1359/jbmr.070721

51. Palsgaard J, Emanuelli B, Winnay JN, Sumara G, Karsenty G, Kahn CR. Cross-talk between insulin and Wnt signaling in preadipocytes: role of Wnt co-receptor low density lipoprotein receptor-related protein-5 (LRP5). J Biol Chem (2012) 287:12016-26. doi:10.1074/jbc.M111.337048

52. Tseng YH, Kokkotou E, Schulz TJ, Huang TL, Winnay JN, Taniguchi CM, et al. New role of bone morphogenetic protein 7 in brown adipogenesis and energy expenditure. Nature (2008) 454:1000-4. doi:10.1038/nature07221

53. Bowers RR, Kim JW, Otto TC, Lane MD. Stable stem cell commitment to the adipocyte lineage by inhibition of DNA methylation: role of the BMP-4 gene. Proc Natl Acad Sci U S A (2006) 103:13022-7. doi:10.1073/pnas.0605789103

54. Wozney JM. The bone morphogenetic protein family and osteogenesis. Mol Reprod Dev (1992) 32:160-7. doi:10.1002/mrd.1080320212

55. Guntur AR, Rosen CJ. IGF-1 regulation of key signaling pathways in bone. Bonekey Rep (2013) 2:437. doi:10.1038/bonekey.2013.171

56. Rosen ED, MacDougald OA. Adipocyte differentiation from the inside out. Nat Rev Mol Cell Biol (2006) 7:885-96. doi:10.1038/nrm2066

57. Zhang Y, Li R, Meng Y, Li S, Donelan W, Zhao Y, et al. Irisin stimulates browning of white adipocytes through mitogen-activated protein kinase $\mathrm{p} 38$ MAP kinase and ERK MAP kinase signaling. Diabetes (2014) 63:514-25. doi:10.2337/db13-1106

58. Colaianni G, Cuscito C, Mongelli T, Oranger A, Mori G, Brunetti G, et al. Irisin enhances osteoblast differentiation in vitro. Int J Endocrinol (2014) (2014):902186. doi:10.1155/2014/902186

59. Colaianni G, Cuscito C, Mongelli T, Pignataro P, Buccoliero C, Liu P, et al. The myokine irisin increases cortical bone mass. Proc Natl Acad Sci U S A (2015) 112:12157-62. doi:10.1073/pnas.1516622112

60. Dutchak PA, Katafuchi T, Bookout AL, Choi JH, Yu RT, Mangelsdorf DJ, et al. Fibroblast growth factor-21 regulates PPARgamma activity and the antidiabetic actions of thiazolidinediones. Cell (2012) 148:556-67. doi:10.1016/j. cell.2011.11.062

61. Wei W, Dutchak PA, Wang X, Ding X, Wang X, Bookout AL, et al. Fibroblast growth factor 21 promotes bone loss by potentiating the effects of peroxisome proliferator-activated receptor gamma. Proc Natl Acad Sci U S A (2012) 109:3143-8. doi:10.1073/pnas. 1200797109

62. Okada A, Yamasaki S, Koga T, Kawashiri SY, Tamai M, Origuchi T, et al. Adipogenesis of the mesenchymal stromal cells and bone oedema in rheumatoid arthritis. Clin Exp Rheumatol (2012) 30:332-7.

63. Ahdjoudj S, Lasmoles F, Holy X, Zerath E, Marie PJ. Transforming growth factor beta2 inhibits adipocyte differentiation induced by skeletal unloading in rat bone marrow stroma. J Bone Miner Res (2002) 17:668-77. doi:10.1359/ jbmr.2002.17.4.668

64. Vanella L, Sodhi K, Kim DH, Puri N, Maheshwari M, Hinds TD, et al. Increased heme-oxygenase 1 expression in mesenchymal stem cell-derived adipocytes decreases differentiation and lipid accumulation via upregulation of the canonical Wnt signaling cascade. Stem Cell Res Ther (2013) 4:28. doi:10.1186/scrt176

65. Li M, Kim DH, Tsenovoy PL, Peterson SJ, Rezzani R, Rodella LF, et al. Treatment of obese diabetic mice with a heme oxygenase inducer reduces visceral and subcutaneous adiposity, increases adiponectin levels, and improves insulin sensitivity and glucose tolerance. Diabetes (2008) 57:1526-35. doi: $10.2337 / \mathrm{db} 07-1764$

66. MacDougald A. Transcriptional regulation of gene expression during adipocyte differentiation. Annu Rev Biochem (1993) 64:345-73. doi:10.1146/ annurev.bi.64.070195.002021

67. Gimble JM, Robinson CE, Wu X, Kelly KA, Rodriguez BR, Kliewer SA, et al. Peroxisome proliferator-activated receptor-gamma activation by thiazolidinediones induces adipogenesis in bone marrow stromal cells. Mol Pharmacol (1996) 50:1087-94.

68. Rosen ED, Hsu CH, Wang X, Sakai S, Freeman MW, Gonzalez FJ, et al. C/ EBPalpha induces adipogenesis through PPARgamma: a unified pathway. Genes Dev (2002) 16:22-6. doi:10.1101/gad.948702

69. Akune T, Ohba S, Kamekura S, Yamaguchi M, Chung UI, Kubota N, et al. PPARgamma insufficiency enhances osteogenesis through osteoblast formation from bone marrow progenitors. J Clin Invest (2004) 113:846-55. doi:10.1172/JCI200419900

70. Jones JR, Barrick C, Kim KA, Lindner J, Blondeau B, Fujimoto Y, et al. Deletion of PPARgamma in adipose tissues of mice protects against high fat diet-induced obesity and insulin resistance. Proc Natl Acad Sci U S A (2005) 102:6207-12. doi:10.1073/pnas.0306743102

71. Lecka-Czernik B. Bone loss in diabetes: use of antidiabetic thiazolidinediones and secondary osteoporosis. Curr Osteoporos Rep (2010) 8:178-84. doi:10.1007/s11914-010-0027-y

72. Qian SW, Li X, Zhang YY, Huang HY, Liu Y, Sun X, et al. Characterization of adipocyte differentiation from human mesenchymal stem cells in bone marrow. BMC Dev Biol (2010) 10:47. doi:10.1186/1471-213X-10-47

73. Linhart HG, Ishimura-Oka K, DeMayo F, Kibe T, Repka D, Poindexter B, et al. C/EBPalpha is required for differentiation of white, but not brown, adipose tissue. Proc Natl Acad Sci U S A (2001) 98:12532-7. doi:10.1073/ pnas. 211416898

74. Tanaka T, Yoshida N, Kishimoto T, Akira S. Defective adipocyte differentiation in mice lacking the C/EBPbeta and/or C/EBPdelta gene. EMBO J (1997) 16:7432-43. doi:10.1093/emboj/16.24.7432

75. Zuo Y, Qiang L, Farmer SR. Activation of CCAAT/enhancer-binding protein (C/EBP) alpha expression by C/EBP beta during adipogenesis requires a peroxisome proliferator-activated receptor-gamma-associated repression of HDAC1 at the C/ebp alpha gene promoter. J Biol Chem (2006) 281:7960-7. doi:10.1074/jbc.M510682200

76. Zanotti S, Stadmeyer L, Smerdel-Ramoya A, Durant D, Canalis E. Misexpression of CCAAT/enhancer binding protein beta causes osteopenia. J Endocrinol (2009) 201:263-74. doi:10.1677/JOE-08-0514

77. Staiger J, Lueben MJ, Berrigan D, Malik R, Perkins SN, Hursting SD, et al. $\mathrm{C} / \mathrm{EBPb}$ ta regulates body composition, energy balance-related hormones and tumor growth. Carcinogenesis (2009) 30:832-40. doi:10.1093/carcin/ $\operatorname{bgn} 273$

78. Tominaga H, Maeda S, Hayashi M, Takeda S, Akira S, Komiya S, et al. CCAAT/enhancer-binding protein beta promotes osteoblast differentiation by enhancing Runx2 activity with ATF4. Mol Biol Cell (2008) 19:5373-86. doi:10.1091/mbc.E08-03-0329

79. Turner RT, Kalra SP, Wong CP, Philbrick KA, Lindenmaier LB, Boghossian S, et al. Peripheral leptin regulates bone formation. J Bone Miner Res (2013) 28:22-34. doi:10.1002/jbmr.1734 
80. Kajimura D, Lee HW, Riley KJ, Arteaga-Solis E, Ferron M, Zhou B, et al. Adiponectin regulates bone mass via opposite central and peripheral mechanisms through FoxO1. Cell Metab (2013) 17:901-15. doi:10.1016/j. cmet.2013.04.009

81. Shi Y, Yadav VK, Suda N, Liu XS, Guo XE, Myers MG Jr, et al. Dissociation of the neuronal regulation of bone mass and energy metabolism by leptin in vivo. Proc Natl Acad Sci U S A (2008) 105:20529-33. doi:10.1073/pnas.0808701106

82. Aprath-Husmann I, Rohrig K, Gottschling-Zeller H, Skurk T, Scriba D, Birgel $\mathrm{M}$, et al. Effects of leptin on the differentiation and metabolism of human adipocytes. Int J Obes Relat Metab Disord (2001) 25:1465-70. doi:10.1038/ sj.ijo. 0801737

83. Oshima K, Nampei A, Matsuda M, Iwaki M, Fukuhara A, Hashimoto J, et al. Adiponectin increases bone mass by suppressing osteoclast and activating osteoblast. Biochem Biophys Res Commun (2005) 331:520-6. doi:10.1016/j. bbrc.2005.03.210

84. Lin YY, Chen CY, Chuang TY, Lin Y, Liu HY, Mersmann HJ, et al. Adiponectin receptor 1 regulates bone formation and osteoblast differentiation by GSK3beta/beta-catenin signaling in mice. Bone (2014) 64:147-54. doi:10.1016/j. bone.2014.03.051

85. Yu L, Tu Q, Han Q, Zhang L, Sui L, Zheng L, et al. Adiponectin regulates bone marrow mesenchymal stem cell niche through a unique signal transduction pathway: an approach for treating bone disease in diabetes. Stem Cells (2015) 33:240-52. doi:10.1002/stem.1844

86. Cawthorn WP, Scheller EL, Learman BS, Parlee SD, Simon BR, Mori H, et al. Bone marrow adipose tissue is an endocrine organ that contributes to increased circulating adiponectin during caloric restriction. Cell Metab (2014) 20:368-75. doi:10.1016/j.cmet.2014.06.003

87. Lagathu C, Christodoulides C, Tan CY, Virtue S, Laudes M, Campbell M, et al. Secreted frizzled-related protein 1 regulates adipose tissue expansion and is dysregulated in severe obesity. Int J Obes (Lond) (2010) 34:1695-705. doi:10.1038/ijo.2010.107

88. Bennett CN, Ross SE, Longo KA, Bajnok L, Hemati N, Johnson KW, et al. Regulation of Wnt signaling during adipogenesis. J Biol Chem (2002) 277:30998-1004. doi:10.1074/jbc.M204527200

89. Laborda J. The role of the epidermal growth factor-like protein dlk in cell differentiation. Histol Histopathol (2000) 15:119-29.

90. Wang Y, Sul HS. Ectodomain shedding of preadipocyte factor 1 (Pref-1) by tumor necrosis factor alpha converting enzyme (TACE) and inhibition of adipocyte differentiation. Mol Cell Biol (2006) 26:5421-35. doi:10.1128/ MCB.02437-05

91. Jensen CH, Krogh TN, Stoving RK, Holmskov U, Teisner B. Fetal antigen 1 (FA1), a circulating member of the epidermal growth factor (EGF) superfamily: ELISA development, physiology and metabolism in relation to renal function. Clin Chim Acta (1997) 268:1-20. doi:10.1016/S0009-8981(97) 00152-6

92. Smas CM, Sul HS. Molecular mechanisms of adipocyte differentiation and inhibitory action of pref-1. Crit Rev Eukaryot Gene Expr (1997) 7:281-98. doi:10.1615/CritRevEukarGeneExpr.v7.i4.10

93. Wolfrum C, Shih DQ, Kuwajima S, Norris AW, Kahn CR, Stoffel M. Role of Foxa-2 in adipocyte metabolism and differentiation. JClin Invest (2003) 112:345-56. doi:10.1172/JCI18698

94. Li D, Yea S, Li S, Chen Z, Narla G, Banck M, et al. Kruppel-like factor-6 promotes preadipocyte differentiation through histone deacetylase 3-dependent repression of DLK1. J Biol Chem (2005) 280:26941-52. doi:10.1074/jbc. M500463200

95. Wu J, Srinivasan SV, Neumann JC, Lingrel JB. The KLF2 transcription factor does not affect the formation of preadipocytes but inhibits their differentiation into adipocytes. Biochemistry (2005) 44:11098-105. doi:10.1021/ bi050166i

96. Abdallah BM, Ding M, Jensen CH, Ditzel N, Flyvbjerg A, Jensen TG, et al. Dlk1/FAl is a novel endocrine regulator of bone and fat mass and its serum level is modulated by growth hormone. Endocrinology (2007) 148:3111-21. doi:10.1210/en.2007-0171

97. Abdallah BM, Ditzel N, Laborda J, Karsenty G, Kassem M. DLK1 regulates whole-body glucose metabolism: a negative feedback regulation of the osteocalcin-insulin loop. Diabetes (2015) 64:3069-80. doi:10.2337/db14-1642

98. Logan CY, Nusse R. The Wnt signaling pathway in development and disease. Annu Rev Cell Dev Biol (2004) 20:781-810. doi:10.1146/annurev. cellbio.20.010403.113126
99. Liu J, Farmer SR. Regulating the balance between peroxisome proliferator-activated receptor gamma and beta-catenin signaling during adipogenesis. A glycogen synthase kinase 3beta phosphorylation-defective mutant of beta-catenin inhibits expression of a subset of adipogenic genes. J Biol Chem (2004) 279:45020-7. doi:10.1074/jbc.M407050200

100. Frost M, Andersen TE, Yadav V, Brixen K, Karsenty G, Kassem M. Patients with high-bone-mass phenotype owing to Lrp5-T253I mutation have low plasma levels of serotonin. J Bone Miner Res (2010) 25:673-5. doi:10.1002/ jbmr.44

101. Cui Y, Niziolek PJ, MacDonald BT, Zylstra CR, Alenina N, Robinson DR, et al. Lrp5 functions in bone to regulate bone mass. Nat Med (2011) 17:684-91. doi: $10.1038 / \mathrm{nm} .2388$

102. Bowers RR, Lane MD. A role for bone morphogenetic protein- 4 in adipocyte development. Cell Cycle (2007) 6:385-9. doi:10.4161/cc.6.4.3804

103. Gustafson B, Smith U. The WNT inhibitor Dickkopf 1 and bone morphogenetic protein 4 rescue adipogenesis in hypertrophic obesity in humans. Diabetes (2012) 61:1217-24. doi:10.2337/db11-1419

104. Yu-Hua T. Bone morphogenetic proteins and adipocyte differentiation. Cell Sci Rev (2007) 3:1-18.

105. Asahina I, Sampath TK, Hauschka PV. Human osteogenic protein-1 induces chondroblastic, osteoblastic, and/or adipocytic differentiation of clonal murine target cells. Exp Cell Res (1996) 222:38-47. doi:10.1006/ excr.1996.0005

106. Wang EA, Israel DI, Kelly S, Luxenberg DP. Bone morphogenetic protein-2 causes commitment and differentiation in C3H10T1/2 and 3T3 cells. Growth Factors (1993) 9:57-71. doi:10.3109/08977199308991582

107. Kim YJ, Lee MH, Wozney JM, Cho JY, Ryoo HM. Bone morphogenetic protein-2-induced alkaline phosphatase expression is stimulated by Dlx 5 and repressed by Msx2. J Biol Chem (2004) 279:50773-80. doi:10.1074/jbc M404145200

108. Chen D, Ji X, Harris MA, Feng JQ, Karsenty G, Celeste AJ, et al. Differential roles for bone morphogenetic protein (BMP) receptor type IB and IA in differentiation and specification of mesenchymal precursor cells to osteoblast and adipocyte lineages. J Cell Biol (1998) 142:295-305. doi:10.1083/ jcb.142.1.295

109. Czech MP, Tencerova M, Pedersen DJ, Aouadi M. Insulin signalling mechanisms for triacylglycerol storage. Diabetologia (2013) 56:949-64. doi:10.1007/ s00125-013-2869-1

110. Sheng MH, Zhou XD, Bonewald LF, Baylink DJ, Lau KH. Disruption of the insulin-like growth factor-1 gene in osteocytes impairs developmental bone growth in mice. Bone (2013) 52:133-44. doi:10.1016/j.bone.2012.09.027

111. Govoni KE, Wergedal JE, Florin L, Angel P, Baylink DJ, Mohan S. Conditional deletion of insulin-like growth factor-I in collagen type 1alpha2-expressing cells results in postnatal lethality and a dramatic reduction in bone accretion. Endocrinology (2007) 148:5706-15. doi:10.1210/en.2007-0608

112. Xian L, Wu X, Pang L, Lou M, Rosen CJ, Qiu T, et al. Matrix IGF-1 maintains bone mass by activation of mTOR in mesenchymal stem cells. Nat Med (2012) 18:1095-101. doi:10.1038/nm.2793

113. Smith PJ, Wise LS, Berkowitz R, Wan C, Rubin CS. Insulin-like growth factor-I is an essential regulator of the differentiation of 3T3-L1 adipocytes. J Biol Chem (1988) 263:9402-8.

114. Bostrom P, Wu J, Jedrychowski MP, Korde A, Ye L, Lo JC, et al. A PGC1alpha-dependent myokine that drives brown-fat-like development of white fat and thermogenesis. Nature (2012) 481:463-8. doi:10.1038/ nature 10777

115. Itoh N. FGF21 as a hepatokine, adipokine, and myokine in metabolism and diseases. Front Endocrinol (2014) 5:107. doi:10.3389/fendo.2014.00107

116. Hanks LJ, Gutierrez OM, Bamman MM, Ashraf A, McCormick KL, Casazza K. Circulating levels of fibroblast growth factor- 21 increase with age independently of body composition indices among healthy individuals. J Clin Transl Endocrinol (2015) 2:77-82. doi:10.1016/j.jcte.2015.02.001

117. Geiser AG, Hummel CW, Draper MW, Henck JW, Cohen IR, Rudmann DG, et al. A new selective estrogen receptor modulator with potent uterine antagonist activity, agonist activity in bone, and minimal ovarian stimulation. Endocrinology (2005) 146:4524-35. doi:10.1210/en.2005-0024

118. Choy L, Derynck R. Transforming growth factor-beta inhibits adipocyte differentiation by Smad3 interacting with CCAAT/enhancer-binding protein (C/EBP) and repressing C/EBP transactivation function. J Biol Chem (2003) 278:9609-19. doi:10.1074/jbc.M212259200 
119. Constant VA, Gagnon A, Landry A, Sorisky A. Macrophage-conditioned medium inhibits the differentiation of 3T3-L1 and human abdominal preadipocytes. Diabetologia (2006) 49:1402-11. doi:10.1007/s00125-0060253-0

120. Suzawa M, Takada I, Yanagisawa J, Ohtake F, Ogawa S, Yamauchi T, et al. Cytokines suppress adipogenesis and PPAR-gamma function through the TAK1/TAB1/NIK cascade. Nat Cell Biol (2003) 5:224-30. doi:10.1038/ ncb942

121. Lumeng CN, Deyoung SM, Saltiel AR. Macrophages block insulin action in adipocytes by altering expression of signaling and glucose transport proteins. Am J Physiol Endocrinol Metab (2007) 292:E166-74. doi:10.1152/ ajpendo.00284.2006

122. Gustafson B, Smith U. Cytokines promote Wnt signaling and inflammation and impair the normal differentiation and lipid accumulation in 3T3-L1 preadipocytes. J Biol Chem (2006) 281:9507-16. doi:10.1074/jbc. M512077200

123. Pricola KL, Kuhn NZ, Haleem-Smith H, Song Y, Tuan RS. Interleukin-6 maintains bone marrow-derived mesenchymal stem cell stemness by an ERK1/2-dependent mechanism. JCell Biochem (2009) 108:577-88. doi:10.1002/jcb.22289

124. Yoon DS, Kim YH, Lee S, Lee KM, Park KH, Jang Y, et al. Interleukin-6 induces the lineage commitment of bone marrow-derived mesenchymal multipotent cells through down-regulation of Sox 2 by osteogenic transcription factors. FASEB J (2014) 28:3273-86. doi:10.1096/fi.13-248567

125. Poli V, Balena R, Fattori E, Markatos A, Yamamoto M, Tanaka H, et al. Interleukin- 6 deficient mice are protected from bone loss caused by estrogen depletion. EMBO J (1994) 13:1189-96.

126. Ivey KN, Srivastava D. MicroRNAs as regulators of differentiation and cell fate decisions. Cell Stem Cell (2010) 7:36-41. doi:10.1016/j.stem.2010. 06.012

127. Taipaleenmaki H, Bjerre Hokland L, Chen L, Kauppinen S, Kassem M. Mechanisms in endocrinology: micro-RNAs: targets for enhancing osteoblast differentiation and bone formation. Eur J Endocrinol (2012) 166:359-71. doi:10.1530/EJE-11-0646

128. Hamam D, Ali D, Vishnubalaji R, Hamam R, Al-Nbaheen M, Chen L, et al. microRNA-320/RUNX2 axis regulates adipocytic differentiation of human mesenchymal (skeletal) stem cells. Cell Death Dis (2014) 5:e1499. doi:10.1038/cddis.2014.462

129. Hamam D, Ali D, Kassem M, Aldahmash A, Alajez NM. microRNAs as regulators of adipogenic differentiation of mesenchymal stem cells. Stem Cells Dev (2015) 24:417-25. doi:10.1089/scd.2014.0331

130. Clark EA, Kalomoiris S, Nolta JA, Fierro FA. Concise review: MicroRNA function in multipotent mesenchymal stromal cells. Stem Cells (2014) 32:1074-82. doi:10.1002/stem.1623

131. Rzonca SO, Suva LJ, Gaddy D, Montague DC, Lecka-Czernik B. Bone is a target for the antidiabetic compound rosiglitazone. Endocrinology (2004) 145:401-6. doi:10.1210/en.2003-0746

132. Tornvig L, Mosekilde LI, Justesen J, Falk E, Kassem M. Troglitazone treatment increases bone marrow adipose tissue volume but does not affect trabecular bone volume in mice. Calcif Tissue Int (2001) 69:46-50. doi:10.1007/ s002230020018

133. van Staa TP, Leufkens B, Cooper C. Bone loss and inhaled glucocorticoids. N Engl J Med (2002) 346:533-5. doi:10.1056/NEJM200202143460716

134. van Staa TP, Leufkens HG, Cooper C. The epidemiology of corticosteroid-induced osteoporosis: a meta-analysis. Osteoporos Int (2002) 13:777-87. doi:10.1007/s001980200108

135. Bredella MA, Fazeli PK, Miller KK, Misra M, Torriani M, Thomas BJ, et al. Increased bone marrow fat in anorexia nervosa. J Clin Endocrinol Metab (2009) 94:2129-36. doi:10.1210/jc.2008-2532

136. Bennett JH, Joyner CJ, Triffitt JT, Owen ME. Adipocytic cells cultured from marrow have osteogenic potential. J Cell Sci (1991) 99(Pt 1):131-9.

137. Song L, Tuan RS. Transdifferentiation potential of human mesenchymal stem cells derived from bone marrow. FASEB J (2004) 18:980-2.

138. Schilling T, Kuffner R, Klein-Hitpass L, Zimmer R, Jakob F, Schutze N. Microarray analyses of transdifferentiated mesenchymal stem cells. JCell Biochem (2008) 103:413-33. doi:10.1002/jcb.21415

139. Moerman EJ, Teng K, Lipschitz DA, Lecka-Czernik B. Aging activates adipogenic and suppresses osteogenic programs in mesenchymal marrow stroma/ stem cells: the role of PPAR-gamma2 transcription factor and TGF-beta/
BMP signaling pathways. Aging Cell (2004) 3:379-89. doi:10.1111/j.14749728.2004.00127.x

140. Lecka-Czernik B. Marrow fat metabolism is linked to the systemic energy metabolism. Bone (2012) 50:534-9. doi:10.1016/j.bone.2011.06.032

141. Bredella MA, Torriani M, Ghomi RH, Thomas BJ, Brick DJ, Gerweck AV, et al. Vertebral bone marrow fat is positively associated with visceral fat and inversely associated with IGF-1 in obese women. Obesity (Silver Spring) (2011) 19:49-53. doi:10.1038/oby.2010.106

142. Di Bernardo G, Messina G, Capasso S, Del Gaudio S, Cipollaro M, Peluso G, et al. Sera of overweight people promote in vitro adipocyte differentiation of bone marrow stromal cells. Stem Cell Res Ther (2014) 5:4. doi:10.1186/ scrt393

143. Cao JJ, Sun L, Gao H. Diet-induced obesity alters bone remodeling leading to decreased femoral trabecular bone mass in mice. Ann N Y Acad Sci (2010) 1192:292-7. doi:10.1111/j.1749-6632.2009.05252.x

144. Casado-Diaz A, Santiago-Mora R, Dorado G, Quesada-Gomez JM. The omega- 6 arachidonic fatty acid, but not the omega-3 fatty acids, inhibits osteoblastogenesis and induces adipogenesis of human mesenchymal stem cells: potential implication in osteoporosis. Osteoporos Int (2013) 24:1647-61. doi:10.1007/s00198-012-2138-z

145. Fillmore N, Huqi A, Jaswal JS, Mori J, Paulin R, Haromy A, et al. Effect of fatty acids on human bone marrow mesenchymal stem cell energy metabolism and survival. PLoS One (2015) 10:e0120257. doi:10.1371/journal.pone. 0120257

146. de Oliveira GP, Cortez E, Araujo GJ, de Carvalho Sabino KC, Neves FA, Bernardo AF, et al. Impaired mitochondrial function and reduced viability in bone marrow cells of obese mice. Cell Tissue Res (2014) 357:185-94. doi:10.1007/s00441-014-1857-1

147. Botolin S, McCabe LR. Bone loss and increased bone adiposity in spontaneous and pharmacologically induced diabetic mice. Endocrinology (2007) 148:198-205. doi:10.1210/en.2006-1006

148. Shanbhogue VV, Hansen S, Frost M, Jorgensen NR, Hermann AP, Henriksen $\mathrm{JE}$, et al. Bone geometry, volumetric density, microarchitecture, and estimated bone strength assessed by HR-pQCT in adult patients with type 1 diabetes mellitus. J Bone Miner Res (2015) 30:2188-99. doi:10.1002/jbmr.2573

149. Shanbhogue VV, Hansen S, Frost M, Jorgensen NR, Hermann AP, Henriksen JE, et al. Compromised cortical bone compartment in type 2 diabetes mellitus patients with microvascular disease. Eur J Endocrinol (2016) 174:115-24. doi:10.1530/EJE-15-0860

150. Vestergaard P. Diabetes and bone fracture: risk factors for old and young. Diabetologia (2014) 57:2007-8. doi:10.1007/s00125-014-3338-1

151. Wei J, Ferron M, Clarke CJ, Hannun YA, Jiang H, Blaner WS, et al. Bonespecific insulin resistance disrupts whole-body glucose homeostasis via decreased osteocalcin activation. J Clin Invest (2014) 124:1-13. doi:10.1172/ JCI72323

152. Wei J, Hanna T, Suda N, Karsenty G, Ducy P. Osteocalcin promotes beta-cell proliferation during development and adulthood through Gprc6a. Diabetes (2014) 63:1021-31. doi:10.2337/db13-0887

153. van Bezooijen RL, Roelen BA, Visser A, van der Wee-Pals L, de Wilt E, Karperien M, et al. Sclerostin is an osteocyte-expressed negative regulator of bone formation, but not a classical BMP antagonist. J Exp Med (2004) 199:805-14. doi:10.1084/jem.20031454

154. Ma YH, Schwartz AV, Sigurdsson S, Hue TF, Lang TF, Harris TB, et al. Circulating sclerostin associated with vertebral bone marrow fat in older men but not women. J Clin Endocrinol Metab (2014) 99:E2584-90. doi:10.1210/ jc.2013-4493

155. McClung MR, Grauer A. Romosozumab in postmenopausal women with osteopenia. N Engl J Med (2014) 370:1664-5. doi:10.1056/NEJMoa1305224

156. Qiang YW, Barlogie B, Rudikoff S, Shaughnessy JD Jr. Dkk1-induced inhibition of Wnt signaling in osteoblast differentiation is an underlying mechanism of bone loss in multiple myeloma. Bone (2008) 42:669-80. doi:10.1016/j.bone.2007.12.006

157. Gennari L, Rotatori S, Bianciardi S, Nuti R, Merlotti D. Treatment needs and current options for postmenopausal osteoporosis. Expert Opin Pharmacother (2016) 17:1141-52. doi:10.1080/14656566.2016.1176147

158. Florio M, Gunasekaran K, Stolina M, Li X, Liu L, Tipton B, et al. A bispecific antibody targeting sclerostin and DKK-1 promotes bone mass accrual and fracture repair. Nat Commun (2016) 7:11505. doi:10.1038/ncomms 11505 
159. Beck GR Jr, Khazai NB, Bouloux GF, Camalier CE, Lin Y, Garneys LM, et al. The effects of thiazolidinediones on human bone marrow stromal cell differentiation in vitro and in thiazolidinedione-treated patients with type 2 diabetes. Transl Res (2013) 161:145-55. doi:10.1016/j.trsl.2012.08.006

160. Grey A, Beckley V, Doyle A, Fenwick S, Horne A, Gamble G, et al. Pioglitazone increases bone marrow fat in type 2 diabetes: results from a randomized controlled trial. Eur J Endocrinol (2012) 166:1087-91. doi:10.1530/ EJE-11-1075

161. Meier C, Schwartz AV, Egger A, Lecka-Czernik B. Effects of diabetes drugs on the skeleton. Bone (2016) 82:93-100. doi:10.1016/j.bone.2015.04.026
Conflict of Interest Statement: The authors declare that the research was conducted in the absence of any commercial or financial relationships that could be construed as a potential conflict of interest.

Copyright (C) 2016 Tencerova and Kassem. This is an open-access article distributed under the terms of the Creative Commons Attribution License (CC BY). The use, distribution or reproduction in other forums is permitted, provided the original author(s) or licensor are credited and that the original publication in this journal is cited, in accordance with accepted academic practice. No use, distribution or reproduction is permitted which does not comply with these terms. 